\title{
SLOVENSKE ALPE - KULTURNA POKRAJINA - NARAVNI PARK - ŠPORTNA ARENA?
}

\begin{abstract}
Matjaž Jeršič
Izvleček

UDK $379.8(234.2$

V prispevku so prikazane spremembe turističnih motivov in njihov vpliv na oblikovanje alpskih turističnih krajev. Podane so primerjave med izbranimi turističnimi kraji $v$ Sloveniji in razvitimi turističnimi območji $v$ drugih delih Alp. Avtor obravnava probleme in dileme o nadaljnjem razvoju turističnih območij.

Ključne besede: Alpe, turistično ravnanje, značilnosti ciljnih območij, učinki, politika in usmerjanje

SLOVENIAN ALPS - CULTURAL LANDSCAPE - NATURAL PARK - SPORTS ARENA?

\section{Abstract}

The article presents the changes of tourist motives and their influence on the formation of Alpine tourist centers. Presented are the comparisons of the selected tourist centers in Slovenia with the developed tourist areas in other parts of the Alps. The author discusses the problems and dilemmas about the further development of tourist regions.
\end{abstract}

Key words: Alps, tourist behavior, destination characteristics, impacts, policy and regulation

\footnotetext{
${ }^{*}$ Dr., red. univ. prof. v p., 1000 Ljubljana, Dermotova 11, Republika Slovenija
} 


\section{UČINKI TURISTIČNIH MOTIVOV NA VREDNOTENJE ALPSKE POKRAJINE}

S 50 milijoni počitniških gostov letno in več kot 100 milijoni izletniških turistov so Alpe največja sklenjena turistična regija na svetu. Učinki turizma so zato že vrsto let predmet znanstvenega, $\mathrm{v}$ zadnjih treh desetletjih pa vedno bolj tudi političnega zanimanja.

V letih od 1880 do 1914 je prišlo do prve pomembnejše turistične ekspanzije in s tem do začetkov učinkovanja turizma na alpsko pokrajino. Osrednja turistična privlačnost $\mathrm{v}$ tem obdobju turističnega razvoja je bila estetika alpske pokrajine. Agrarna kulturna pokrajina, sestavljena iz različnih zemljiških kategorij, divjih, skalnih in ledeniških območij ter posameznih naravnih objektov (sotesk, slapov, jezer idr.) je pomenila glavno privlačno dobrino turistične ponudbe. Številne alpske fotografije na razglednicah, prospektih in koledarjih temeljijo še danes na estetskih načelih, ki so se oblikovala v 18. in 19. stoletju. Hkrati dokazujejo, da velik del turistov še danes ceni te estetske kategorije Alp (Bätzing, W., 1991).

Tudi v prvem obdobju sodobnega, na poletni čas vezanega množičnega turizma, ki se je začel po letu 1955, je bila glavna turistična dobrina doživljajska zmožnost alpske pokrajine. V naslednjem obdobju množičnega turizma, ki se je začelo z alpskim smučanjem, nekako po letu 1965, pa se začenja obdobje, v katerem vse bolj stopa v ospredje športna dejavnost alpskih obiskovalcev. S tem so se začela številna alpska območja oblikovati v "športne regije", v katerih se turisti čez dan ukvarjajo predvsem s telesno dejavnostjo, pozimi s smučanjem, medtem ko opoldanski in večerni čas preživijo v družabnem okolju (npr. v diskoklubu, restavraciji, bazenu). Pri velikem delu te skupine turistov je v ospredju doživljanje v smučarski vožnji, ki jo omogočajo ustrezne in zanimive smučarske proge, žičnice in gorske restavracije. Doživljanje pokrajine je pri številnih smučarjih v ozadju, zato je za mnoge od njih alpska pokrajina le "kulisa", vedno bolj pomembna pa je tehnična infrastruktura (Bätzing, W., 1991).

Tako sta bili po letu 1965 v Alpah značilni dve glavni skupini gostov: prva so bili tradicionalni poletni turisti, druga pa "moderno" usmerjeni zimskošportni turisti. Prva je prihajala predvsem zaradi estetike alpske pokrajine in se je ukvarjala s sprehodi, planinskimi izleti, alpinističnimi vzponi ali se prevažala z gorskimi železnicami, druga, večinoma mlajša skupina, pa je bila motivirana pretežno s športnimi dejavnostmi, sprva zlasti smučanjem. Medtem ko se je do srede sedemdesetih let prva skupina postopoma zoževala, je druga številčno stalno naraščala, v nekaterih obdobjih celo z dvoštevilčno stopnjo rasti.

$\mathrm{V}$ drugi polovici osemdesetih let je prišlo do sprememb tudi v času poletne turistične sezone. Z uveljavljanjem življenjskih vrednot: "biti zdrav", "biti fit", "biti telesno zmogljiv", se je začelo povečevati število ljudi, ki so želeli počitnice v Alpah preživeti ob aktivnem športnem udejstvovanju. $\mathrm{S}$ tem so se tradicionalnemu planinstvu in alpinizmu pridružile številne, deloma modno pogojene in visoko 
specializirane športne dejavnosti, s katerimi so se ukvarjali alpski turisti. Značilni primeri takih v poletnem času so gorsko kolesarjenje, kajakaštvo, rafting, tenis, jahanje, golf, taborjenje, športno plezanje, jadralno padalstvo, v zimskem času pa hoja in tek na smučeh, deskanje na snegu, športno plezanje $\mathrm{v}$ ledu, vožnja $\mathrm{z}$ motornimi sanmi, jadralno padalstvo (Jeršič, M., 1997).

Ker je za velik del novih športnih dejavnosti potrebna športna infrastruktura, skušajo nosilci turistične ponudbe zanje zagotoviti objekte, ki bi bili neodvisni od vetra in padavin. Ta prizadevanja terjajo vedno več različnih tehničnih naprav in to ne samo na prostem, temveč tudi v pokritih prostorih, saj se posamezne dejavnosti, ki so bile nekdaj navezane le na odprto pokrajino, selijo tudi $\mathrm{v}$ dvorane, kot npr. športno plezanje, kopanje, tenis, drsanje, jahanje.

Zaradi opisanih sprememb v navadah turistov Alpe niso, tako kot nekdaj, turistično privlačne le zaradi lepe, kulturne in naravne pokrajine, temveč za mnoge predvsem kot regija, kjer se lahko ukvarjajo s priljubljenim športom.

Bätzing je prepričan, da so napredujoča tehnizacija, avtomatizacija in specializacija na vseh življenjskih področjih vplivale tudi na odnos ljudi do narave, ki je pri mnogih vedno manj neposreden in čutno globok. Zato mnogi uživajo naravo le s hotelske terase, skozi avtomobilsko okno, iz žičnice ali po televiziji.

Iz omenjenega je razvidno, da so se želje in potrebe turistov spremenile in hkrati postale tudi bolj različne. Nosilci turistične ponudbe so prisiljeni, da opremljajo pokrajino z novimi in raznovrstnimi rekreacijskimi napravami. Ta proces pospešuje težnja po ohranitvi konkurenčne sposobnosti, ki sili posamezne turistične kraje $\mathrm{v}$ gradnjo novih objektov turistične ponudbe. Primeri take usmeritve so vedno hitrejše in udobnejše žičnice, razvejeno omrežje smučarskih prog, naprave za umetno zasneževanje, igrišča za golf in pokrita športna igrišča.

\section{RAZVOJNE USMERITVE ALPSKIH TURISTIČNIH KRAJEV}

Zimskošportni množični turizem se je v letih od 1965 do 1981 izredno hitro razvijal in povzročil, da so številni alpski turistični kraji postali dvosezonski. To je ugodno vplivalo na njihov gospodarski položaj in na zagotavljanje stalnih delovnih mest. Kot posebej ugodna za turistični razvoj so se pokazala območja na nadmorskih višinah med 1.200 do $2.000 \mathrm{~m}$, še posebej pa tista okrog $1.500 \mathrm{~m}$, ki so omogočala visoko izkoriščenost turističnih zmogljivosti. Poleti je namreč $v$ teh višinah na splošno še razmeroma toplo in s tem primerno za rekreacijo na prostem, hkrati pa je pozimi snežna odeja dokaj zanesljiva. Nižje ležeči gorski turistični kraji so doživljali močnejši turistični razvoj v glavnem le tam, kjer so jih z žičnicami povezali z višje ležečimi smučarskimi območji (Hannss, C., Schröder, P., 1985).

Po letu 1981 se v Alpah turistično povpraševanje ni več povečevalo. To pa je dodatno zaostrilo tekmovanje med alpskimi zimskošportnimi kraji, saj so se turistični objekti 
kljub temu še naprej gradili. To neskladje je v osemdesetih letih povzročilo presežke turističnih zmogljivosti. V tem tržnem boju so večja zimskošportna središča bila gospodarsko uspešnejša in so zato lažje izboljševala svojo turistično ponudbo, zlasti modernizirala žičnice ali gradila naprave za umetno zasneževanje. Posledica tega je bila, da so v osemdesetih letih veliki zimskošportni kraji oziroma območja pridobili monopolni turistični položaj. Ko so se v devetdesetih letih poleg zimskih močneje uveljavile tudi nove poletne športne dejavnosti in $\mathrm{z}$ njimi pobujene zahteve po nadaljnji gradnji rekreacijske tehnične infrastrukture (npr. igrišča za golf, pokrita kopališča, trim kabineti), se je zaradi visokih stroškov monopolni položaj velikih alpskih turističnih središč še bolj krepil.

$\mathrm{Ob}$ povečani zavesti o pomembnosti ohranjanja okolja je v zadnjih letih prišlo do spoznanja, da gorskega sveta ni mogoče preprosto zgolj tehnično opremiti, ne da bi si hkrati prizadevali tudi za njegovo ekološko stabilnost. To je vplivalo na izvedbo številnih sanacijskih in negovalnih ukrepov, ponekod pa privedlo tudi do bolj ali manj uspešnih poskusov omejevanja nadaljnjega kvantitativnega turističnega razvoja. Tako so na primer zmogljivosti smučišč povečevali znotraj obstoječih smučarskih območij, niso pa odpirali nova.

Iz povedanega je razvidno, da je turizem v Alpah po drugi svetovni vojni pomembno učinkoval na alpsko pokrajino. Za preoblikovanje je bilo poleg same množičnosti pomembno zlasti to, da se je turistično povpraševanje diferenciralo, tako da se je na eni strani oblikovala skupina tistih obiskovalcev, ki v gorskem svetu iščejo stik $\mathrm{z}$ naravo in njeno uživanje, na drugi strani pa tistih, ki se želijo $\mathrm{v}$ gorah ukvarjati predvsem s športnimi dejavnostmi. Prav slednja skupina je vplivala na tehnizacijo gorskih območij in hkrati na oblikovanje velikih monostrukturnih in monopolnih turističnih središč, ki so se gospodarsko lažje prilagajala vedno večjim zahtevam po tehnični, zlasti zimskošportni infrastrukturi.

\section{PROBLEMATIČNI UČINKI TURIZMA}

Opisani razvoj je poleg pozitivnih učinkov povzročil tudi številne problematične. Med pozitivnimi je nedvomno na prvem mestu dejstvo, da je v številnih alpskih regijah turizem edina ali glavna eksistenčna dejavnost. Brez turizma bi bila številna območja Alp danes že razseljena.

In kateri problematični učinki posebej izstopajo zaradi nenadzorovane rasti turistične ponudbe? V zelo zoženi in posplošeni obliki povzemamo le najpomembnejše:

- Gospodarski učinki. Izrazita časovna koncentracija turističnega povpraševanja ponekod ovira rentabilno gradnjo in delovanje splošne in turistične infrastrukture. Zmogljivosti teh naprav so prilagojene časovno omejenemu vrhuncu sezone, zaradi česar je izkoriščenost razmeroma nizka. Hkrati sili konkurenčni boj posamezne kraje $\mathrm{V}$ gradnjo nedonosnih objektov. Vprašljiva je tudi 
monostrukturnost številnih alpskih turističnih regij, ki povzroča njihovo enostransko odvisnost od ene same gospodarske dejavnosti. Pri tem ne gre samo za odvisnost od gospodarskih konjunkturnih gibanj, temveč tudi od muhaste narave. Ta nevarnost je prišla do veljave $\mathrm{v}$ osemdesetih letih, to je $\mathrm{v}$ zimah 1987/88 do 1989/90, ko so zaradi pomanjkanja snega tudi v višjih legah številni alpski turistični kraji, zlasti lastniki transportnih naprav (žičnic), zašli v velike finančne izgube. Prav ta problem je sprožil pospešeno opremljanje gorskih območjih z napravami za umetno zasneževanje, torej dodatno poseganje v gorsko naravo.

- Okolje in pokrajina. $\mathrm{V}$ ospredje razgovorov o obremenitvi okolja so silili $\mathrm{V}$ zadnjih dvajsetih letih predvsem posegi zaradi urejanja smučarskih prog in umetnega zasneževanja.

- Med problematičnimi vplivi urejanja smučišč moramo omeniti predvsem: spreminjanje danih reliefnih razmer, odstranjevanje vegetacije v večjih višinah, krčenje gozda ob zgornji meji, spreminjanje vodnih razmer z erozijskimi pojavi, uničevanje redkih biotopov, zoževanje življenjskega prostora divjadi itd. Okoljski problem $\mathrm{v}$ širšem pomenu je tudi krnitev pokrajinskega videza in historične dediščine ter tehnizacija pokrajine.

- V zadnjem času se posebej poudarja problem "prodiranja" obiskovalcev v sorazmerno naravne in posebej občutljive dele gorske narave, kot so stene, soteske in gorske reke in rečice, ki postajajo "zanimive" za nove oblike rekreacijskih dejavnosti, kot so rafting, kajakaštvo, soteskanje, športno plezanje. Zaradi tega so nekateri prepričani, da ni smiselno govoriti o "trdih" in "mehkih" rekreacijskih dejavnostih, saj lahko tudi t. i. mehke ogrožajo okolje.

- V razvitih turističnih regijah Alp prihaja v turistični sezoni do takega povečanja števila občasnih prebivalcev, ki ustreza majhnim ali srednje velikim mestom. Emisije zraka so $\mathrm{v}$ takih območjih podobne kot $\mathrm{v}$ mestnih območjih, njihov negativni učinek pa povečujejo reliefne razmere.

- Socialno-kulturni problemi. Med domačim prebivalstvom in turisti ali med domačini in zunanjimi nosilci turistične ponudbe je prišlo ponekod do gospodarskih in političnih nasprotij. O tem problemu je sicer le malo znanstvenih raziskav. Splošno znano pa je, da turistična dejavnost, podobno kot številne druge, kaže težnjo po profesionalizaciji zaposlenih. To se kaže v specializiranih menedžerskih delovnih mestih, ki jih $\mathrm{v}$ turističnem kraju pogosto zasedajo tujci. V mnogih turističnih območjih posamezni domači prebivalci s plačevanjem davkov prispevajo v občinski proračun, s čimer pomagajo razvijati tudi turizem, vendar od njega nimajo koristi. Agrarna kulturna pokrajina se uporablja tudi kot rekreacijski prostor za sprehode, izlete, hojo in tek na smučeh ter druge dejavnosti na prostem. Vendar za rekreacijsko souporabo teh površin kmetje ne dobivajo odškodnine. Prav tako se $\mathrm{v}$ turističnih občinah pomembne odločitve pogosto sprejemajo pod vplivom hotelirjev, zastopnikov gradbenih agencij in žičniških podjetij, katerih sedež je zunaj Alp. Zaradi vplivov nedomačinov razvojne odločitve niso vedno v korist alpske regije ali kraja. Poseben problem je lahko 
tudi visoka cena zemljišč, ki je $\mathrm{v}$ razvitih turističnih krajih pogosto taka kot $\mathrm{v}$ središčih večjih mest. Posledica je, da domače prebivalstvo zemljišč skoraj ne more kupiti (Scharpf, H., 1980).

Iz pregleda možnih problematičnih učinkov turizma lahko povzamemo, da je na eni strani za turistični razvoj intaktna pokrajina in kulturna raznolikost nepogrešljiv pogoj turističnega razvoja, da pa na drugi strani turizem negativno vpliva na pokrajino, pogosto tudi do take mere, da ogroža, ponekod pa celo uničuje lastne temelje.

\section{TURISTIČNI RAZVOJ V SLOVENSKIH ALPAH}

Ali je šel turistični razvoj v slovenskih Alpah po opisani poti? Ali učinki in problemi, ki jih zasledimo v kritičnih bilancah o turističnem razvoju, veljajo tudi za naš del alpskega sveta?

Že v prvem obdobju, to je v času turističnega odkrivanja Alp (1780-1880), so tudi slovensko alpsko pokrajino pričeli obiskovati raziskovalci, zlasti botaniki in geologi (npr. B. Hacquet se je 1. 1790 povzpel na Mali Triglav, A. Scopoli pa 1. 1759 na Grintovec), za njimi pa tudi prvi planinci.

V turističnem obdobju t.i. "Belle-Epoque" (1880-1914) je prišlo v slovenskih Alpah do gradnje planinskih koč ter nadelave in markiranja planinskih poti. Vzporedno so se pričeli v alpskih dolinah razvijati tudi turistični kraji, predvsem Bled, Bohinjska Bistrica, Kranjska gora in Jezersko.

Če preskočimo medvojno obdobje, lahko ugotovimo, da obdobje poletnega množičnega turizma po letu 1955 v slovenskih Alpah ni pustilo pomembnejših sledov, če zanemarimo gradnjo novih planinskih poti ter koč. V ospredju takratne razvojne strategije naše države je bila industrializacija. V nekatere alpske doline so se tedaj razširila območja dnevne delovne migracije, ponekod pa so tudi znotraj Alp nastala manjša industrijska središča. Tako ni presenetljivo, da so se predvojne turistične zmogljivosti $\mathrm{v}$ povojnih letih $\mathrm{v}$ nekaterih alpskih turističnih krajih celo zmanjšale (npr. na Bledu, v Bohinju, na Jezerskem).

V obdobju po letu 1955, za katerega je bil značilen hitro razvijajoč zimski množični turizem, se je pozornost turističnega načrtovanja usmerila tudi v alpske pokrajine. $\mathrm{V}$ gorskem svetu Slovenije so pričeli preučevati možnosti za ureditev smučarske infrastrukture, še posebej v višjem svetu po zgledu francoskih zimskošportnih krajev "iz retorte", ki naj bi bili optimalno prirejeni potrebam zimskošportnih turistov.

Velik del teh načrtov je ostal neuresničen in to predvsem iz dveh razlogov:

- Reliefna oblikovanost na večjih nadmorskih višinah ni ustrezna za oblikovanje razvejenih smučarskih prog različnih težavnostnih stopenj, ki bi jih bilo možno povezati v razsežna omrežja oziroma sisteme, poimenovane "skicirkus". Posamezna potencialno ustrezna območja bi bilo za smučanje treba preurediti s pomembnejšimi spremembami reliefa ali jih zavarovati s protierozijskimi posegi. 
Ker je $\mathrm{Z}$ gospodarskega vidika opremljanje visokogorskih območij Z zimskošportno infrastrukturo smiselno le v primeru visoke zmogljivosti smučišč, ki omogoča množično in s tem rentabilno delovanje teh naprav, so bili številni projekti tudi gospodarsko sporni.

- Kljub hitri rasti zimskošportnega povpraševanja, zlasti v letih od 1970 do 1981 , in prizadevanjem po intenzivnejšem "vključevanju gorskega sveta $\mathrm{v}$ zimski turizem" se je pojavilo tudi strateško vprašanje, koliko gorskega sveta naj namenimo tehnično intenzivnemu turističnemu razvoju, zlasti ob dejstvu, da ima Slovenija le majhen "kos" alpske pokrajine.

Navedeno je vplivalo na turistični razvoj, ki ga lahko primerjalno označimo takole:

- Površinski obseg smučišč ob velikih alpskih smučarskih središčih zunaj Slovenije je bistveno večji, v njih so smučarske žičnice praviloma speljane na nadmorskih višinah nad $2.000 \mathrm{~m}$, dolžina omrežja prog posameznih območij pogosto presega $100 \mathrm{~km}$, proge pa so marsikje speljane preko gorskih slemen $\mathrm{v}$ sosednje doline, kjer se združujejo s smučišči drugih središč.

- Smučarska infrastruktura $\mathrm{v}$ posameznih območjih Slovenije je tako po zmogljivosti kot po površini mnogo manjša. V slovenski alpski pokrajini se torej niso oblikovali "giganti" z ozemeljsko obsežno, močno tehnizirano in urbanizirano turistično pokrajino. Priložene skice in podatki za izbrana smučarska središča to nazorno prikazujejo. V slovenskih turističnih pokrajinah zato pojav turistične zasičenosti $\mathrm{z}$ vsemi spremljajočimi problemi ne sili tako močno $\mathrm{v}$ ospredje kot v mnogih drugih delih Alp (Ski Atlas, 1996). 
Slika 1: Smučarska območja v delu Savojskih Alp (Francija)

\section{Smučarska območja v delu Savojskih Alp (Francija)}

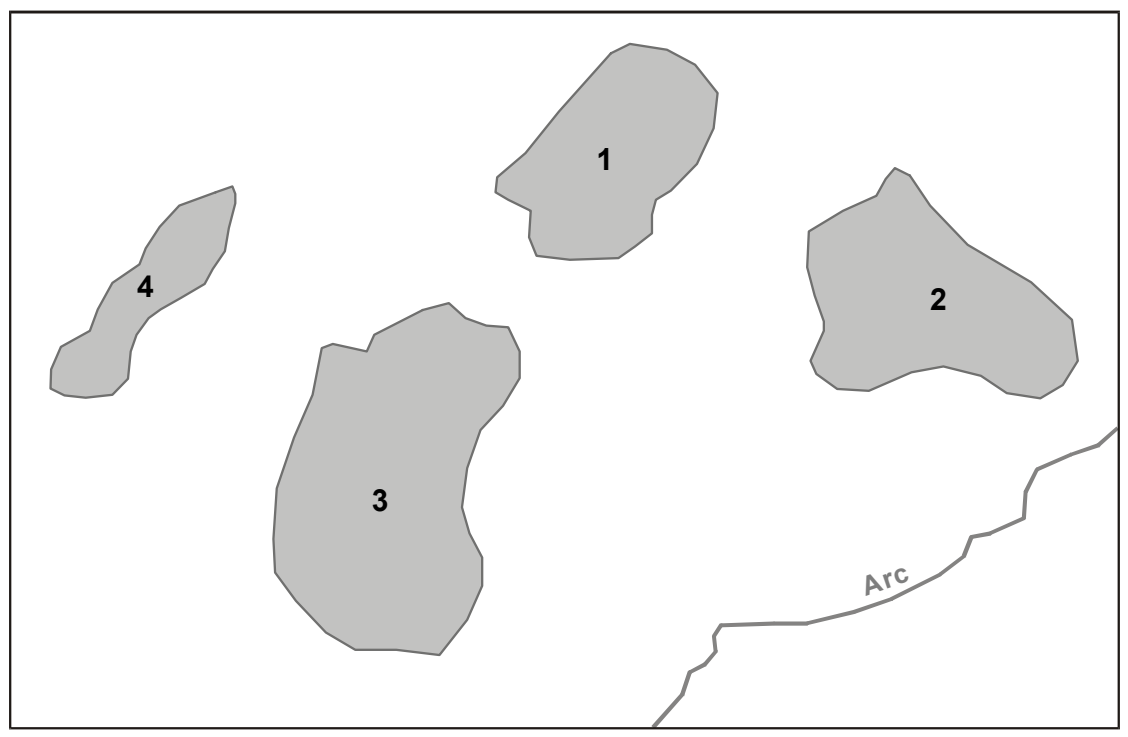

Tab. 1. Smučarska območja v delu Savojskih Alp (Francija)

\begin{tabular}{|c|l|c|c|c|c|}
\hline $\begin{array}{c}\text { Št. na } \\
\text { karti }\end{array}$ & \multicolumn{1}{|c|}{ Ime } & $\begin{array}{c}\text { Višinski pas } \\
\text { smučišča }(\mathrm{m})\end{array}$ & $\begin{array}{c}\text { Višinska } \\
\text { razlika }(\mathrm{m})\end{array}$ & $\begin{array}{c}\text { Skupna dolžina } \\
\text { prog }(\mathrm{km})\end{array}$ & $\begin{array}{c}\text { Število } \\
\text { ležišč }\end{array}$ \\
\hline 1 & La Plagne & $1250-3250$ & 2000 & 210 & 45000 \\
2 & Val d'Isere & $1550-3650$ & 2100 & 300 & 54000 \\
3 & Les Trois Vallées & $1300-3300$ & 200 & 600 & 105000 \\
4 & St. Francois, Valmorel & $1400-2550$ & 1150 & 165 & 13500 \\
\hline & & & 1275 & 127500 \\
\hline
\end{tabular}


Slika 2: Smučarska območja v Wallisu (Švica)

Smučarska območja v Wallisu (Švica)

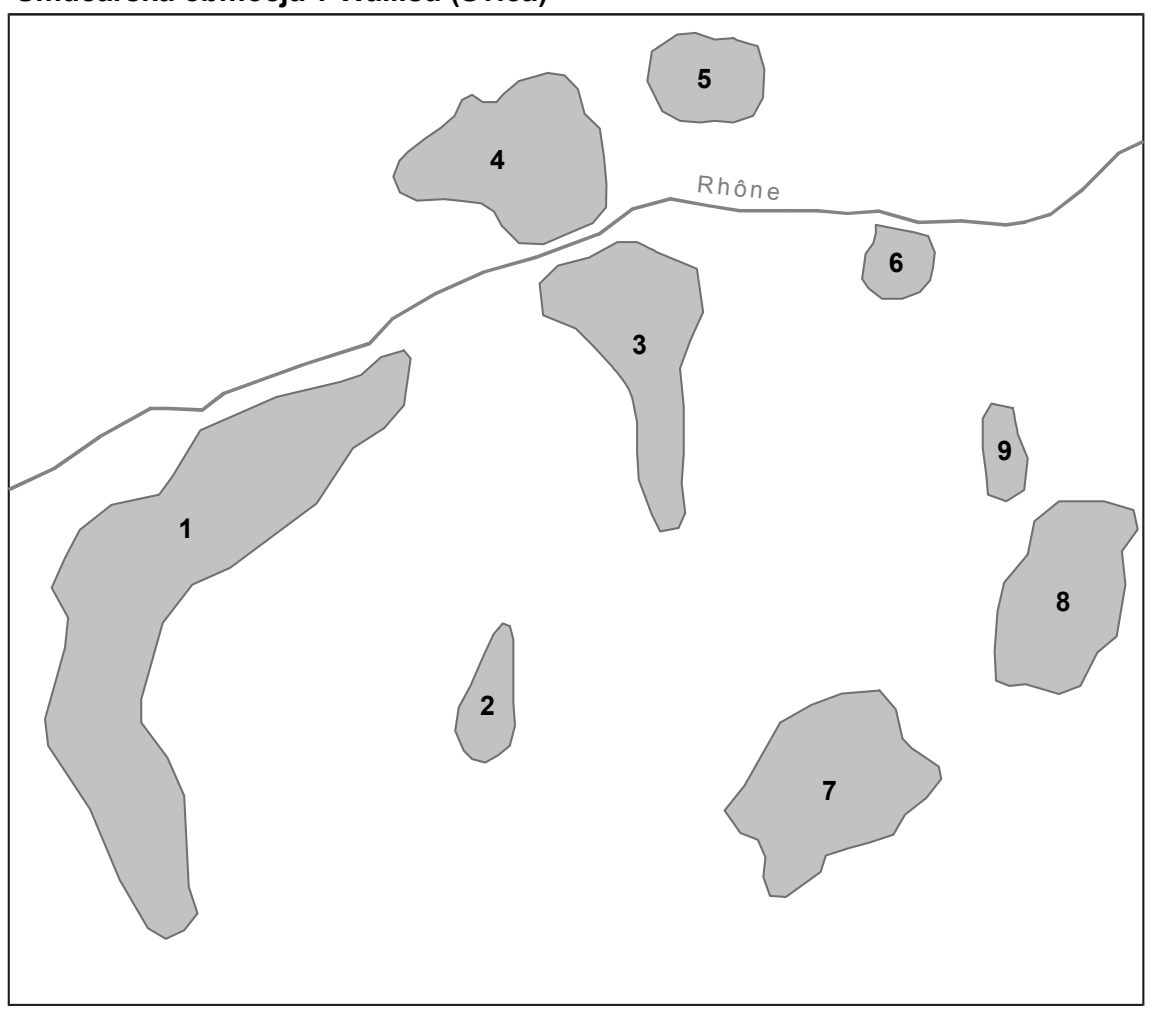

Tab. 2. Smučarska območja v Wallisu (Švica)

\begin{tabular}{|c|l|c|c|c|c|}
\hline $\begin{array}{c}\text { Št. na } \\
\text { karti }\end{array}$ & \multicolumn{1}{|c|}{ Ime } & $\begin{array}{c}\text { Višinski pas } \\
\text { smučišča }(\mathrm{m})\end{array}$ & $\begin{array}{c}\text { Višinska } \\
\text { razlika }(\mathrm{m})\end{array}$ & $\begin{array}{c}\text { Skupna dolžina } \\
\text { prog }(\mathrm{km})\end{array}$ & $\begin{array}{c}\text { Število } \\
\text { ležǐšc }\end{array}$ \\
\hline 1 & Les Quatre Vallées & $821-3330$ & 2509 & 400 & 45000 \\
2 & Val d'Herens & $1371-1998$ & 627 & 50 & 2000 \\
3 & Val d'Anniviers & $1322-1934$ & 612 & 230 & 14800 \\
4 & Crans Montana & $1500-3000$ & 1500 & 200 & 47500 \\
5 & Leukerbad & $1411-2700$ & 1289 & 40 & 8000 \\
6 & Augstbord & $1200-2540$ & 1340 & 95 & 7700 \\
7 & Zermatt & $1620-3889$ & 2269 & 230 & 11000 \\
8 & Saas Fee & $1800-3600$ & 1800 & 80 & 8500 \\
9 & Grächen & $1600-2920$ & 1320 & 44 & 5000 \\
\hline & Skupaj & & 1369 & 149500 \\
\hline
\end{tabular}


Slika 3: Smučarska območja v delu Dolomitov (Italija)

\section{Smučarska območja v delu Dolomitov (Italija)}

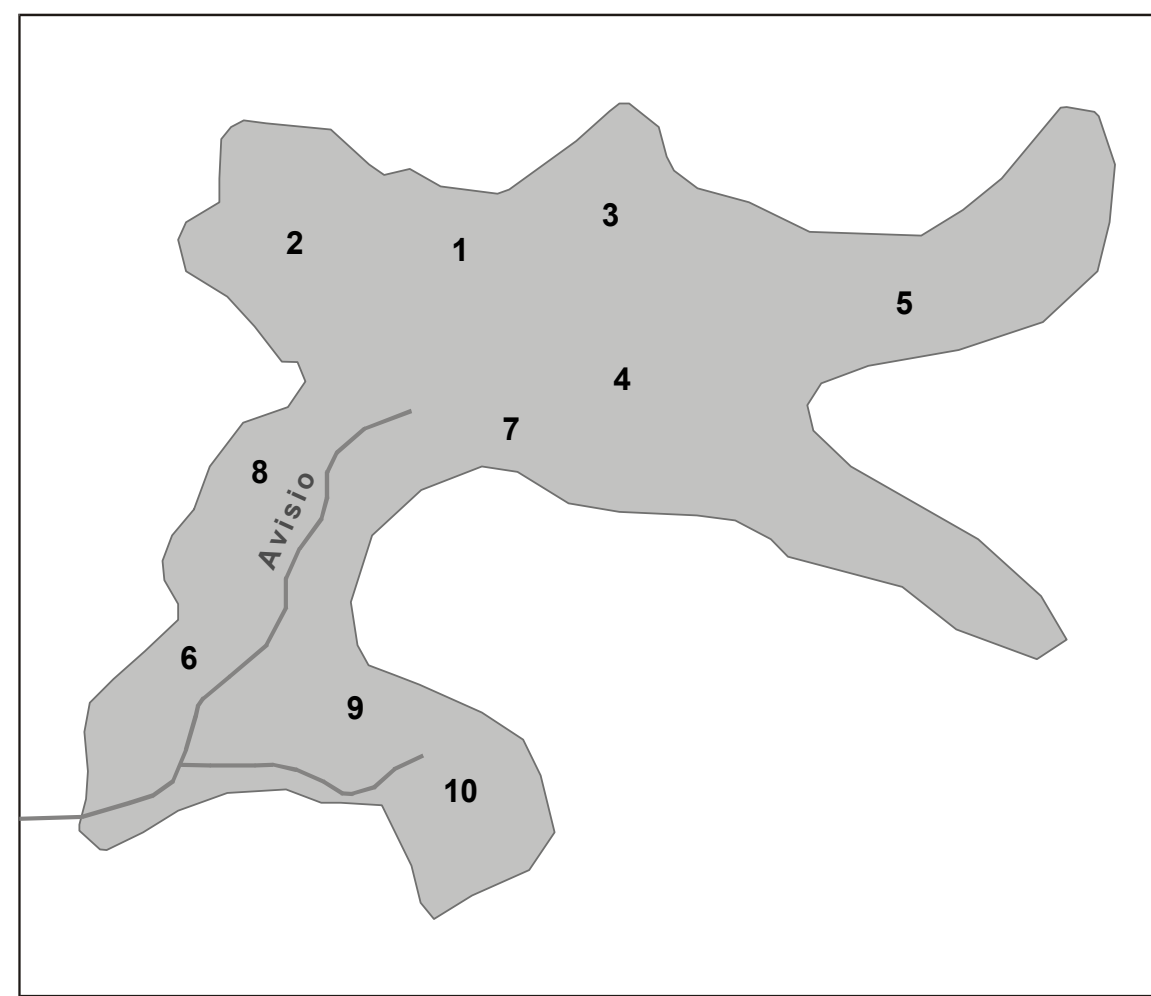

Tab.3. Smučarska območja v delu Dolomitov (Italija)

\begin{tabular}{|c|l|c|c|c|c|}
\hline $\begin{array}{c}\text { Št. na } \\
\text { karti }\end{array}$ & $\begin{array}{c}\text { Višinski pas } \\
\text { smučišča }(\mathrm{m})\end{array}$ & $\begin{array}{c}\text { Višinska } \\
\text { razlika }(\mathrm{m})\end{array}$ & $\begin{array}{c}\text { Skupna dolžina } \\
\text { prog }(\mathrm{km})\end{array}$ & $\begin{array}{c}\text { Śtevilo } \\
\text { ležišč }\end{array}$ \\
\hline 1 & Val Gardena & $1236-2680$ & 1444 & 175 & 17000 \\
2 & Schlerngebiet & $1060-2245$ & 1185 & 60 & 7500 \\
3 & Hochabteital, Alta Badia & $1350-2550$ & 1200 & 130 & 13500 \\
4 & Arabba & $1602-2950$ & 1353 & 50 & 1800 \\
5 & Cortina d'Ampezzo & $1224-3243$ & 2019 & 160 & 22500 \\
6 & Obereggen, Latemar & $1126-2400$ & 1274 & 45 & 7000 \\
7 & Marmolada & $1000-3265$ & 2265 & 150 & 4300 \\
8 & Fassatal & $1200-2638$ & 1438 & 145 & 42800 \\
9 & Fleimstal & $952-2489$ & 1537 & 55 & 28400 \\
10 & San Martino di Castrozza & $1450-2230$ & 780 & 50 & 16000 \\
\hline & Skupaj & & 1020 & 160800 \\
\hline
\end{tabular}


Slika 1: Smučarska območja v Julijskih Alpah (Slovenija)

Smučarska območja v Julijskih Alpah (Slovenija)

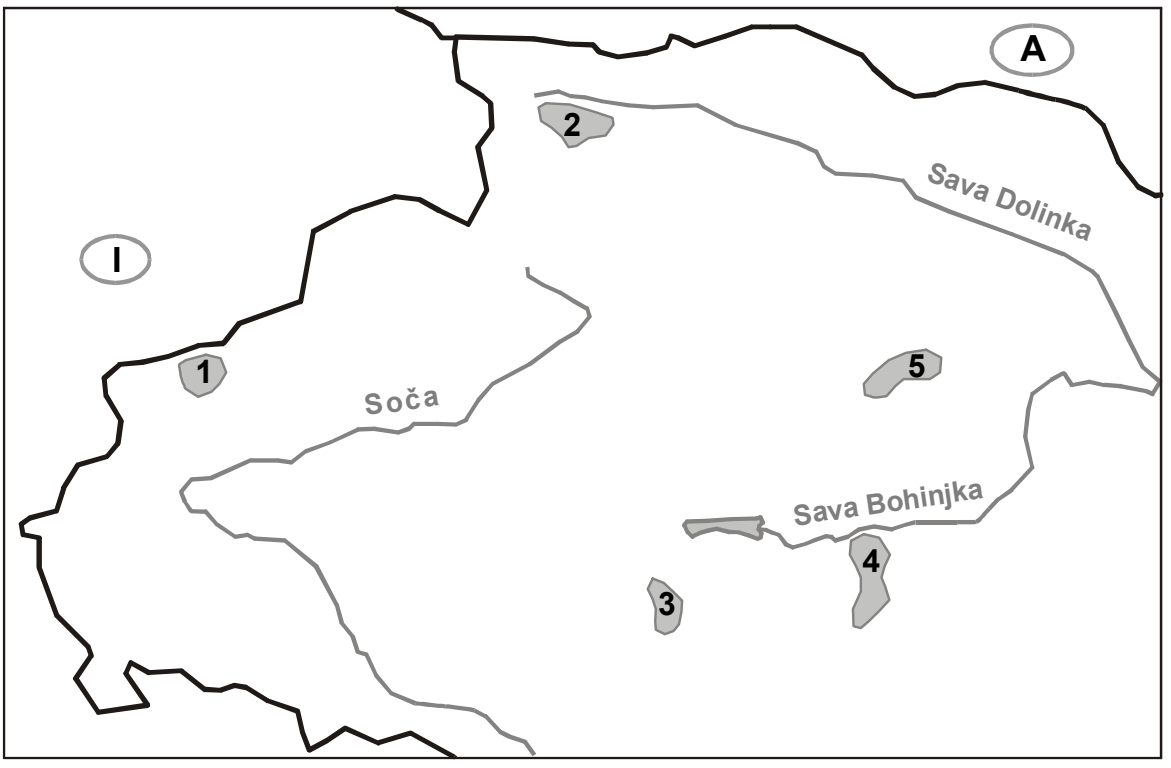

Tab. 4. Smučarska območja v Julijskih Alpah (Slovenija)

\begin{tabular}{|c|l|c|c|c|c|}
\hline $\begin{array}{c}\text { Št. na } \\
\text { karti }\end{array}$ & \multicolumn{1}{|c|}{ Ime } & $\begin{array}{c}\text { Višinski pas } \\
\text { smučišča }(\mathrm{m})\end{array}$ & $\begin{array}{c}\text { Višinska } \\
\text { razlika }(\mathrm{m})\end{array}$ & $\begin{array}{c}\text { Skupna dolžina } \\
\text { prog }(\mathrm{km})\end{array}$ & $\begin{array}{c}\text { Število } \\
\text { ležišč }\end{array}$ \\
\hline 1 & Kanin & $1700-2300$ & 600 & 14 & 1719 \\
2 & Kranjska gora & $810-1530$ & 720 & 30 & 3542 \\
3 & Kobla & $520-1480$ & 960 & 23 & 1587 \\
4 & Vogel & $1070-1750$ & 680 & 36 & 3404 \\
5 & Zatrnik & $900-1240$ & 340 & 3,7 & 0 \\
\hline & Skupaj & & 106,7 & 10252 \\
\hline
\end{tabular}

Vir: Ski Atlas, ADAC 1995

\section{ALTERNATIVNE ZASNOVE TURISTIČNEGA RAZVOJA}

Spoznanje, da je dosedanji razvoj turizma povzročil v Alpah tudi številne probleme, je sprožilo različne pobude za spremembo dosedanjih razvojnih teženj. Z oblikovanjem alternativnih razvojnih zamisli alpskega turizma so se pričele zlasti po letu 1975 ukvarjati različne organizacije. 
Na prvem mestu je treba omeniti zamisel, ki se je pojavila v sedemdesetih letih pod nazivom blagi ali mehki turizem. Blagi turizem v ožjem smislu naj bi bil v primerjavi s sedanjim strukturno alternativna oblika turističnega razvoja. Osrednji elementi te zamisli so: sorazmerno naravna, netehnizirana turistična ponudba (npr. brez žičnic), rekreacijske dejavnosti, ki temeljijo na uporabi lastne človekove energije (npr. hoja, kolesarjenje, veslanje) in na regionalnem pokrajinskem potencialu ter turistične nastanitvene zmogljivosti, ki so energetsko skromne (v primerjavi s sedanjimi manj luksuznimi objekti). V socialno-kulturnem pogledu naj bi šlo za znosen razvoj, ki upošteva domače nosilce razvoja. $\mathrm{V}$ posameznih alpskih pokrajinah so poskušali na teh izhodiščih temelječe modele uresničiti tudi v praksi. Dosedanja prizadevanja za uresničevanje zasnov mehkega turizma v ožjem pomenu so pokazala, da za turistično že razvite regije niso primerne in da jih je možno uveljaviti predvsem v obliki "niš" v turistično še nerazvitih pokrajinah. Primeri uspešne uveljavitve tega koncepta so $\mathrm{v}$ alpski pokrajini za zdaj le parcialni.

Poleg koncepta mehkega turizma v ožjem pomenu so razmišljali tudi o možnosti t.i. blagega turizma $\mathrm{v}$ širšem pomenu. Po tem konceptu naj se $\mathrm{z}$ restriktivnimi ukrepi prostorske in regionalne politike učinkoviteje uskladijo koristi gospodarstva, varstva narave in tudi domačega prebivalstva. Bistveni sestavni del te strategije naj bi torej bile omejitve $\mathrm{v}$ razvoju turistične ponudbe zaradi zmanjšanja ekoloških in socialnih obremenitev. Smotri tega koncepta so se do sedaj uveljavili predvsem z ustanavljanjem naravovarstvenih območij, s katerimi varujejo posamezna alpska območja pred vdorom tehniziranega turizma. Podoben ukrep prostorskega načrtovanja je coniranje pokrajine na območja oziroma cone $\mathrm{z}$ različno rabo. To pomeni, da se pokrajino razčleni na tako imenovana "tabu območja", ki so brez vsake turistične rabe, $\mathrm{v}$ cone, namenjene ekstenzivnim in netehniziranim rekreacijskim dejavnostim ter v območja, kjer naj se osredotoča tudi tehnično intenziven turistični razvoj (Kirstges, 1992). Tak koncept uveljavljajo v celotnem pasu Bavarskih Alp. Tako funkcijo pa ima tudi območje našega Triglavskega parka, ki je Julijske Alpe v osrednjem delu zavaroval pred "trdimi" oblikami rekreacije.

Alternativni razvojni koncepti so se do sedaj uveljavili le v manjšem delu Alp. Raziskovalci poudarjajo, da je za širšo uresničitev konceptov mehkega turizma potrebna sprememba sedanjih turističnih navad oziroma "nova etika" ravnanja turistov. Kaj to pomeni? V številnih anketah se vedno znova pojavljajo odgovori, po katerih je za turiste $\mathrm{v}$ ciljnih turističnih pokrajinah pomembna intaktna in prijazna pokrajina. V nasprotju s temi odgovori pa se povečuje povpraševanje po udobnih hotelih in po raznovrstni turistični infrastrukturi. Zaradi hedonističnih teženj (k uživanju naravnana družba) želijo številni ljudje sicer uživati ohranjeno naravo, prav tako pa hočejo vedno višji standard udobja, udobni hotel ali infrastrukturo, ki jim omogoča ukvarjanje s priljubljeno dejavnostjo. Brez popolne preobrazbe temeljnih vrednot, nagibov in vzorcev obnašanja pa konceptov blagega turizma ni možno širše uveljaviti.

V takem položaju so med ukrepi usmerjanja in uravnoteženja turističnega razvoja, kot smo navedli, že vrsto let uspešni predvsem restriktivni ukrepi, to je zaščita določenih 
območij s prepovedmi, ki se $\mathrm{v}$ prvi vrsti nanašajo na uravnovešanje med turistično intenzivno in ekstenzivno rabljenimi površinami. Razglašanje naravovarstvenih območij, ki ga uveljavljajo v vseh alpskih državah v različnih oblikah, je zato marsikje najpomembnejši obrambni "okop" proti "trdim" oblikam rekreacije. Ob tem se pojavljajo tudi kritike, češ da je vzpostavljanje naravovarstvenih območij alibi, da bi se zunaj njih lahko turizem svobodno nesmotrno razvijal. Ne glede na te očitke $\mathrm{v}$ sedanjih razmerah, ko prevladujejo gospodarske koristi, restriktivni ukrepi pomembno učinkujejo na alpsko pokrajino. Razglašanje zavarovanih območij je smiselno tudi zato, ker so trenutno številni drugi ukrepi oziroma recepti razviti le na načelni ravni. S tem v zvezi naj posebej omenimo problematiko meje rasti. Številni medsebojni učinki v kompleksnem "sistemu turizem" (razmerja med gospodarskimi, ekološkimi in socialnimi vidiki) ter nenehno spreminjanje vrednostnih predstav udeležencev tega sistema relativizirajo številna vprašanja o meji rasti in o zasičenosti zaradi turizma. Absolutni odgovori o mejnih vrednostih, npr. o nosilnosti ekosistemov, o razmerju turistov ali domačih prebivalcev do okolja, niso na razpolago in jih zato pri nadaljnjem razvoju turizma ni mogoče uporabiti. V osnovi sicer obstaja široka enotnost, da je nadaljnjo količinsko rast turističnih zmogljivosti v posameznih območjih treba zavreti, vendar je obremenljivost težko določiti, saj pogosto ni možno natančno utemeljiti, kakšno ekološko stanje naj bi ohranili. To pomeni, da se je o vprašanju o obsegu posegov v pokrajino možno pogosto opredeliti le na podlagi vrednostne sodbe, ki je subjektivna in individualno pogojena. Meje ali robne pogoje sicer lahko določimo kot normativne cilje, vendar jih je zaradi njihove relativnosti potrebno "priznati" le v procesu političnega odločanja.

Globalno načelo, da mora nadaljnja rast turizma sloneti na okolju in socialno znosnem razvoju, je nesporno. To kažejo tudi številni novejši dokumenti o strategijah turističnega razvoja, ki poudarjajo te vidike. Problem pa je v opredeljevanju strokovno utemeljenih in določenih mejnih vrednosti, ki naj to zagotovijo.

Poleg predhodnih dilem se že dolgo vrsto let zastavlja vprašanje o razmerjih med turizmom in kmetijstvom. Vedno znova se poudarja, da je vzporedni proizvod alpskega kmetijstva intaktna, to je estetsko privlačna pokrajina. Prav kmetijska raba je bistveno pripomogla $\mathrm{k}$ drobno razčlenjeni, raznoliki in ekološko pestri alpski pokrajini. Praktične posledice tega spoznanja so razne oblike subvencij in podpor na državnih in lokalnih ravneh, s katerimi se v nasprotju $\mathrm{z}$ ideali svobodnega tržnega gospodarstva evropske unije, vzdržuje kmetijska raba v številnih alpskih pokrajinah. Vedno znova se poudarja, da je agrarna pokrajina s prepletanjem kmetijskih in gozdnih zemljiških kategorij turistično privlačnejša od povsem gozdnate pokrajine. To mnenje lahko podpira ugotovitev, da je omrežje zaznamovanih planinskih poti $\mathrm{v}$ Sloveniji redkejše v pokrajinskih območjih s prevlado gozda in gostejše tam, kjer se gozd prepleta z neogozdenimi površinami in je možna večja razglednost, na primer na robovih izkrčenih planot, grebenih in vrhovih. Prav tako je možno ugotoviti, da so gorske doline, deli planot in krnice, kjer so zaradi agrarne rabe deloma izkrčili gozd, posebej privlačne rekreacijske površine. Kot kažejo številne raziskave to pomeni, da pretirano ogozdovanje zmanjšuje kakovost doživljajskosti pokrajine. Proces 
zaraščanja z gozdom je zato v posameznih pokrajinskih območjih Slovenije trenutno celo bolj akuten kot problemi turističnega zasičenja, saj zmanjšuje obseg posebej privlačnih pokrajinskih delov.

\section{SKLEP}

Slovenski alpski svet se ne uvršča med intenzivno preoblikovane gorske turistične regije. Problemi turistične zasičenosti so zato mnogo manj izraziti kot v številnih drugih alpskih pokrajinah. Slovenija ima zato možnost, da pri nadaljnjem razvoju turizma upošteva negativne razvojne težnje, ki so prišle do izraza v tujih območjih intenzivnejšega turističnega razvoja. Razmeroma skromen turistični razvoj naših alpskih pokrajin lahko sedaj, ko so poleg pozitivnih razvidni tudi problematični učinki turizma, ocenjujemo tudi kot prednost, saj tako stanje olajšuje uveljavljanje ekološko in socialno ustreznejše razvojne strategije.

\section{LITERATURA}

1. Bätzing W., 1991: Die Alpen. Entstehung und Gefährdung einer europäischen Kulturlandschaft. C. H. Beck, München

2. Hannss C., Schröder, P., 1985: Touristische Transportanlagen in den Alpen. Dokumente und Informationen zur Schweizerischen Orts-, Regional- und Landesplanung, Nr. 79. Institut ORL ETH, Zürich

3. Jeršič M., 1997: Turistična rekreacija in urejanje prostora. Academia Turistica 4, Nacionalno turistično združenje, Ljubljana; str. 71-82

4. Kirstges T., 1992: Sanfter Tourismus. R. Oldenbourg V., München - Wien

5. Scharpf H., 1980: Die Belastungsproblematik im Rahmen der Freizeitplanung. Handbuch für Planung, Gestaltung und Schutz der Umwelt, Band 3. BLV, München - Wien - Zürich; str. 345-360

6. Ski Atlas, 1996; ADAC Verlag GMbH, München 


\title{
SLOVENIAN ALPS - CULTURAL LANDSCAPE - NATURAL PARK - SPORTS ARENA?
}

\begin{abstract}
Summary
After 1965, when alpine skiing became popular as the mass form of tourist recreation, the era began in which the sports activity of visitors to the Alps came ever more to the front. In numerous Alpine tourist resorts the tourist infrastructure was built, with which the different needs of recreational activities were satisfied. In Slovenian Alpine world too, the possibilities were being studied, to build the tourist centers after the model of French winter sports centers "from the retort", which should have been optimum adapted to the needs of winter sports tourists. A large percentage of these plans were not implemented since the landforms of the Slovenian Alps were not very suitable for the construction of large-scale ski fields. Besides, firm negative standpoints were formed, against the excessive tourist-oriented technical innovations in the Slovenian Alps, which had a strong impact on the establishing of a national park in the central area of the Julian Alps. However, from the aspect of natural conditions, this area is most suitable for the possible construction of ski fields.

Thus, the Slovenian Alpine world does not rank among the intensely transformed mountainous tourist regions. The problems of tourist saturation are therefore much less explicit in Slovenia than in the other Alpine regions. Nowadays, when also the possible problematic effects are ever more transparent besides the positive effects of tourism, a relatively modest tourist development can also be considered as an advantage because such a situation facilitates the effectuating of ecologically and socially more suitable developmental strategies.
\end{abstract}

